\title{
HOW TO STUDY LITERATURE
}

General Editors: John Peck and Martin Coyle HOW TO STUDY A THOMAS HARDY NOVEL 


\section{IN THE SAME SERIES}

How to Study a Novel John Peck Literary Terms and Criticism'John Peck and Martin Coyle How to Study a Shakespeare Play John Peck and Martin Coyle How to Study a Jane Austen Novel Vivien Jones FURTHER TITLES ARE IN PREPARATION 


\title{
HOW TO STUDY A THOMAS HARDY NOVEL
}

\author{
John Peck
}

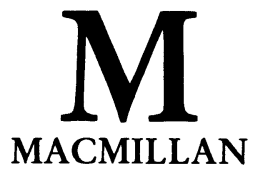




\section{(C) John Peck 1987}

All rights reserved. No reproduction, copy or transmission of this publication may be made without written permission.

No paragraph of this publication may be reproduced, copied or transmitted save with written permission or in accordance with the provisions of the Copyright Act 1956 (as amended).

Any person who does any unauthorised act in relation to this publication may be liable to criminal prosecution and civil claims for damages.

\section{First published 1987}

Published by

Higher and Further Education Division

MACMILLAN PUBLISHERS LTD

Houndmills, Basingstoke, Hampshire RG21 2XS

and London

Companies and representatives

throughout the world

Typeset by Wessex Typesetters

(Division of The Eastern Press Ltd)

Frome, Somerset

British Library Cataloguing in Publication Data

Peck, John, 1947-

How to study a Thomas Hardy novel.

(How to study literature)

1. Hardy, Thomas. 1840-1928-Criticism

and interpretation

I. Title II. Series

823'.8 PR4754 
For Tom 


\section{Contents}

General Editors' Preface

viii

1. Where to begin 1

2. Far from the Madding Crowd 8

3. The Return of the Native 21

4. The Mayor of Casterbridge 34

5. Tess of the D'Urbervilles $\quad 50$

6. Jude the Obscure 64

$\begin{array}{ll}\text { 7. Writing an essay } & 77\end{array}$

8. Discussing an extract 85

A Note on Criticism 93 


\section{General Editors' Preface}

Everybody who studies literature, either for an examination or simply for pleasure, experiences the same problem: how to understand and respond to the text. As every student of literature knows, it is perfectly possible to read a book over and over again and yet still feel baffled and at a loss as to what to say about it. One answer to this problem, of course, is to accept someone else's view of the text, but how much more rewarding it would be if you could work out your own critical response to any book you choose or are required to study.

The aim of this series is to help you develop your critical skills by offering practical advice about how to read, understand and analyse literature. Each volume provides you with a clear method of study so that you can see how to set about tackling texts on your own. While the authors of each volume approach the problem in a different way, every book in the series attempts to provide you with some broad ideas about the kind of texts you are likely to be studying and some broad ideas about how to think about literature; each volume then shows you how to apply these ideas in a way which should help you construct your own analysis and interpretation. Unlike most critical books, therefore, the books in this series do not simply convey someone else's thinking about a text, but encourage you and show you how to think about a text for yourself.

Each book is written with an awareness that you are likely to be preparing for an examination, and therefore practical advice is given not only on how to understand and analyse literature, but also on how to organise a written response. Our hope is that although these books are intended to serve a practical purpose, they may also enrich your enjoyment of literature by making you a more confident reader, alert to the interest and pleasure to be derived from literary texts. 